\title{
CROATIAN CITIES DURING THE COVID-19 CRISIS: CHALLENGES, RESPONSES AND ADJUSTMENTS
}

\author{
Dana Dobrić Jambrović, PhD, Assistant Professor \\ University of Rijeka, Faculty of Law \\ Hahlić 6, 51000 Rijeka \\ ddobric@pravri.hr
}

\begin{abstract}
The main research question of the paper is related to the identification and analysis of the challenges that Croatian local units face during the crisis caused by the COVID-19 pandemic. First, the regulatory framework of the civil protection system was presented to determine a direction of research of organizational and functional adjustments of local units for effective crisis management. Empirical research was conducted using the data content analysis (legal regulations, strategic documents, soft law documents, and web sourced data). Research findings have shown that local units face challenges in the areas of political governance, administrative and professional affairs, local budget, and the implementation of local democracy mechanisms. Therefore, in each of the identified areas, the author has analyzed elements that are subject to adaptation to national recommendations to reduce the spread of coronavirus. In doing so, attention is focused on large cities and county centers and their adjustments during crisis management were analyzed.
\end{abstract}

Keywords: COVID-19, crisis management, Croatia, functional adjustments, local government, organizational adjustments

\section{INTRODUCTION}

In recent decades, a series of transboundary crises have hit countries globally and demanded their cooperation in the field of crisis management. The current crisis is caused by the COVID-19 pandemic. The European Union has taken an active role to connect the national capacities of member states in the fight against a pandemic. In particular, by activating the EU Integrated Political Crisis Response (IPCR) arrangements as a coordination mechanism that brings together all information coming from different actors (member states, international orga- 
nizations, EU institutions). ${ }^{1}$ The ideal solution to a transboundary threat would be a joint state response in terms of arranging decision-making authority across multiple jurisdictions, synchronizing national responses, and facilitating the international exchange of resources. ${ }^{2}$ And COVID-19 should be dealt with in this way. However, given that this is a global pandemic, there are different models of crisis management at the national, and especially at the subnational level, which is the backbone of reducing the pandemic. This paper analyzes the crisis management model applied by Croatian local units within the national regulatory framework.

After a short overview of the current course and management of the COVID-19 crisis in Croatia, the second part of the paper analyzes the legal framework relevant for the civil protection system and protection of the population from infectious diseases. The purpose of this analysis is to identify in which areas the elements of local governance and service delivery need to be adapted. Therefore, the main research question of the paper is the challenges that local units face during crisis management. Given a large number of local units and their uneven structure, this research will cover large cities and cities that have the status of county centers. ${ }^{3}$

The author will examine two hypotheses. First, the crisis will affect the increase in the concentration of political influence in the executive branch. Although the position of executive leaders was strengthened in 2007 with the introduction of direct elections of local executive leaders, ${ }^{4}$ it is assumed that the pandemic contributed to further strengthening of their position and authority. The second hypothesis states that the crisis will additionally reduce the quality of local public services and impose restrictions on local democracy. In the early 1990s, the territory of Croatia was divided into too many small local units. About $60 \%$ of them do not have sufficient administrative or financial capacity for efficient and quality provision of services. ${ }^{5}$ Also, local democracy is underdeveloped in Croatian local

1 Council, The EU Integrated Political Crisis Response - IPCR - Arrangements Government of the Republic of Croatia, Bill on amendments to the Act on the protection of the population from infectious diseases with the Final Bill (PZ n. 921), 9 April 2020).

2 Ansell, C.; Boin, A.; Keller, A., Managing Transboundary Crises: Identifying Building Blocks of an Effective Response System, Journal of Contingencies and Crisis Management, Vol. 18, No. 4, 2010, pp. 195-207.

3 These are Bjelovar, Čakovec, Dubrovnik, Gospić, Karlovac, Kaštela, Koprivnica, Krapina, Osijek, Pazin, Požega, Pula, Rijeka, Samobor, Sisak, Slavonski Brod, Split, Šibenik, Varaždin, Velika Gorica, Vinkovci, Virovitica, Vukovar, Zadar, and Zagreb. The author will use the term "cities" for selected units, and the term "towns" for smaller cities that are not subject to analysis.

4 Koprić, I.; Škarica, M., Evaluacija neposrednog izbora načelnika u Hrvatskoj nakon dva mandata: korak naprijed, dva nazad, in: Gongeta, S.; Smoljić, M. (eds.) Zbornik radova 7. međunarodne konferencije "Razvoj javne uprave”, Veleučilište 'Lavoslav Ružička' u Vukovaru, Vukovar, 2017, pp. 156-172.

5 Koprić, I., Glavna obilježja postojećeg i prijedlog novog teritorijalnog ustrojstva Hrvatske - zašto nam treba teritorijalna reorganizacija, in: Koprić, I. (ed.) Reforma lokalne i regionalne samouprave u Republici 
political arena. Voter turnout in local elections after 2000 is $41 \%$ to $49 \%{ }^{6}$ and they are even less active in direct forms of local governance. Therefore, the crisis is expected to deepen such deficits even further.

For the purpose of testing hypotheses, the third part of the paper analyzes the adjustments implemented in the field of political steering of the crisis management, organization and work of the local administrative system, local finances, and local democracy. Based on the results, the last part contains comments on the given hypotheses and recommendations for better management during a future crisis.

\section{COVID-19 CRISIS MANAGEMENT IN CROATIA (FEBRUARY 2020 TO FEBRUARY 2021)}

At the end of February 2020, before the appearance of the first infections in Croatia, the Government introduced the first significant adjustment. Pursuant to the Civil Protection Act (hereinafter: CPA), ${ }^{7}$ it issued a decision on the appointment of the Chief and members of the National Civil Protection Headquarters (hereinafter: Headquarters), whose primary task was to coordinate all services in the event of a coronavirus outbreak in the country. After the appearance of the first infections, from 25 February 2020, a number of special measures were gradually introduced related to the economy, public services, freedom of movement, etc. Given the growing number of patients, the Minister of Health passed a Decision declaring an epidemic, ${ }^{8}$ in parallel with the decision of the World Health Organization to declare the COVID-19 global pandemic. At that time, regional and local civil protection headquarters began to be activated, cooperating directly with the Headquarters, and the main role in governing the state was taken over by the executive bodies at the central, regional, and local levels.

Since the number of patients increased significantly during March 2020, and the first death occurred, the work of all educational and cultural institutions was suspended. Most catering facilities and shops were closed, while all public transport was suspended along with the prohibition of leaving the place of temporary and permanent residence. It became very predictable what dramatic consequences the

Hrvatskoj, Institut za javnu upravu - Pravni fakultet Zagreb, Zagreb, 2013, p. 29.

6 State Election Commission, [https://www.izbori.hr/site/UserDocsImages/2266], Accessed 2 June 2021.

7 Civil Protection Act, Official Gazette No. 85/15, 118/18, 31/20.

8 Decision on declaring the COVID-19 epidemic caused by the SARS-CoV-2 virus, 2020, [https://zdravstvo.gov.hr/UserDocsImages/2020\%20CORONAVIRUS/ODLUKA\%20O\%20 PROGLA\%C5\%A0ENJU\%20EPIDEMIJE\%20BOLESTI\%20COVID-19.pdf], Accessed 10 February 2021. 
necessary measures would leave on the economy and society. Therefore, by the beginning of April, two packages of Government measures to preserve the liquid-

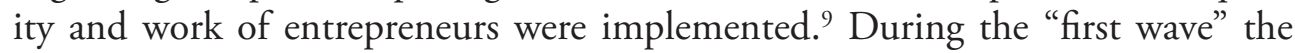
"lockdown" lasted for a month, but the Croatian Parliament did not declare a state of emergency in the country. The first measures of remission followed at the end of April when a decrease in the number of patients was recorded. Apart from the declining number of daily illnesses, there was another important reason for the loosening of measures: on 5 July, the parliamentary elections were held.

Crisis management was assessed as extremely successful during the "first wave." The implemented measures and citizens' discipline very quickly showed good results in terms of a significant decline in the number of new cases. Croatias measures in relation to the number of infected cases were among the most restrictive, which was confirmed by a University of Oxford study and the London company Deep Knowledge Group (DKG). ${ }^{10}$ Their scientists compared the measures taken by countries and the number of their infected cases, and Croatia was at the top of the scale. ${ }^{11}$

However, the favorable situation lasted only two months. At the beginning of December, a dark record of 4,620 new cases in one day was achieved. ${ }^{12}$ This was followed by daily decisions of the Headquarters on necessary epidemiological measures for certain counties, cities, and municipalities, a decision to ban border crossings ${ }^{13}$ and a decision to re-ban citizens outside the counties of their temporary or permanent residence. ${ }^{14}$

It is interesting to note that during the "first wave," only 27 days after the first patient's appearance in Croatia and when the number of patients per day was 48, strict epidemiological measures were introduced. In contrast, analog measures were activated only five months after the start of the "second wave." At that time, the

9 A list and more detailed information on all Government measures is available at: [https://www.koronavirus.hr/vladine-mjere/101], Accessed 13 January 2021.

10 DKG has developed analytical frameworks to analyze economic, social, and geopolitical stability to obtain results. The survey was conducted in 60 countries. Countries were assessed using 24 specific parameters in four different categories, including quarantine efficiency, government management efficiency, monitoring and detection, and emergency preparedness. DKG, [https://www.dkv.global/ covid-safety-assessment-200-regions], Accessed 13 January 2021.

11 For example, on 3 April, the number of infected people was 1,079, and only 8 died (Official Government website for timely and accurate information on the coronavirus, [https://www.koronavirus.hr/], Accessed 12 February 2021). Thus, mortality was $0.741 \%$.

12 Ibid.

13 Decision on the amendment to the Decision on temporary prohibition and restriction of border crossings of the Republic of Croatia, Official Gazette No. 139/20.

14 Decision on the prohibition of leaving the county based on the place of permanent residence or temporary stay in the Republic of Croatia, Official Gazette No. 141/20. 
number of daily cases was almost 100 times higher than during the "first wave". Consequently, crisis management during the "autumn wave" did not achieve the success that was evident in the spring.

\section{CROATIAN LEGISLATIVE FRAMEWORK ON CRISIS MANAGEMENT AND CIVIL PROTECTION SYSTEM}

There are two basic regulations: the CPA and Act on the Protection of the Population from Infectious Diseases (hereinafter: APPID). ${ }^{15}$ The first regulates the system and operation of civil protection, rights and obligations of state administration bodies, local and regional self-government units, legal and natural persons, administrative and inspection supervision, and other. The system is organized at the local, regional, and national level and connects the participants' resources and capabilities, operational forces, and citizens to reduce disaster risk. Regardless of the level, a headquarters performs tasks related to collecting and processing information on the possibility of a major accident and catastrophe, develops an action plan for the civil protection system in its area, performs public information activities and proposes a decision on termination of the implementation of measures and activities in the civil protection system. ${ }^{16}$

Due to the COVID-19, amendments to APPID were initiated. An institutional model of crisis management appropriate to the severity and urgency of the pandemic was established, which enables the realization of the principles of effectiveness and proportionality. Supervision over the achievement of these goals is the responsibility of the Government. ${ }^{17}$ The APPID supplemented the list of infectious diseases with the COVID-19 virus, improved the existing regulation of the measure "isolation at home," and prescribed additional powers to sanitary inspectors to monitor the implementation of measures. During the "autumn wave", new security measures have been introduced - the obligation to wear a face mask, a prohibition/restriction of public and private gatherings. Also, the circle of supervisor of the implementation of safety measures has been expanded. In addition to the Government, supervision is now performed by police officers, inspectors of state administration bodies responsible for civil protection, inspectors of the State Inspectorate, and inspectors of other state administration bodies within their competence. ${ }^{18}$

15 Act on the Protection of the Population from Infectious Diseases, Official Gazette No. 79/07, 113/08, 43/09, 130/17, 114/18, 47/20, 134/20.

16 Art. 21, para. 3 of the CPA.

17 Government, Report on the effects of the implementation of measures under the Act on the Protection of the Population from Infectious Diseases during the COVID-19 pandemic caused by the SARS-COV-2 virus in the Republic of Croatia for the period from 11 March 2020 to 15 January 2021, Zagreb, 2021, p. 3.

18 Ibid. 


\subsection{Civil protection system at the central level}

The Government manages the activities of all participants in the civil protection system with the support of the Headquarters, and the MIA. The Government, at the proposal of the MIA, establishes and appoints the Headquarters. ${ }^{19}$ The Minister of the Interior was appointed Chief of the Headquarters, along with other members, representatives of relevant ministries, the National Institute of Public Health (hereinafter: NIPH), the Croatian Red Cross, the Croatian Mountain Rescue Service, etc. Furthermore, the MIA performs administrative and technical tasks and ensures other conditions for the work of the Headquarters. On the other hand, the state bodies represented in the Headquarters are obliged to provide their representatives with the professional and operational support necessary for the effective implementation of the tasks. ${ }^{20}$ In the event of special circumstances, the management of the Headquarters is taken over by the Prime Minister or a member of the Government authorized by him. The Headquarters is then authorized to make decisions and instructions that are required to be implemented by the headquarters at the local and regional levels. ${ }^{21}$

\subsection{Civil protection system at the subnational levels}

Decisions at the central level are taken in consultation with regional civil protection headquarters. In addition, local units can adopt their own measures that are in line with central authorities' decisions. Municipalities, cities, and counties are obliged to organize activities within their self-governing scope related to the planning, development, efficient functioning, and financing of the civil protection system. Powers in the field of civil protection are shared by the representative and executive body of the unit. Councils/assemblies in the process of adopting the budget adopt the annual plan for the development of the civil protection system with financial effects for a three-year period and guidelines for organization and development of the system which are considered and adopted every four years, and provide financial resources for the execution of decisions on the financing of civil protection activities. In addition, the executive bodies are responsible for adopting a civil protection action plan, submitting to the representative body decisions on establishing civil protection units, deciding on providing material and financial funding for the operational

19 Art. 2 para 1 of the Decision on the composition of the headquarters, the manner of work and the conditions for the appointment of the Chief, Deputy Chief and members of the Civil Protection Headquarters, Official Gazette No. 126/19, 17/20.

20 Art. 15 of the Decision on the composition of the headquarters, the manner of work and the conditions for the appointment of the Chief, Deputy Chief and members of the Civil Protection Headquarters, Official Gazette No. 126/19, 17/20.

21 Art. 22 and 22a of the CPA. 
forces, providing conditions for maintaining the database on members, capabilities and resources of the operational forces, etc. ${ }^{22}$ The executive body also establishes the civil protection headquarters and appoints the chief, deputy chief, unit administrative bodies, and other legal entities of special importance for the civil protection system. Following the example of the central level, the unit's headquarters' work is managed by the Chief. When special circumstances are declared, the management is taken over by the unit executive body. Additionally, the executive body may appoint a civil protection commissioner and his deputy for individual housing, residential buildings, streets, local committees and smaller settlements. They participate in the preparation of citizens for personal and mutual protection, provide information on the timely taking of civil protection measures, organize the protection of members of vulnerable groups, etc. ${ }^{23}$

Finally, the CPA envisages the institute of connecting several local units in the field of civil protection. Therefore, units that belong to the same geographical area and are connected into a single unit can organize a joint performance of civil protection activities. There are several possibilities for co-operation: joint administrative body, joint action plan for civil protection, which is confirmed by the executive bodies of the units, and joint civil protection units. The decision on co-operation is made by the representative bodies and then the executive leaders sign the agreement and submit it to the MIA. ${ }^{24}$ About fifty local units have signed agreements on joint coordination of civil protection activities, establishing a coordinating body for civil protection headquarters. The establishment of coordination enabled unhindered movement without a pass between units that are spatially connected into a single whole. ${ }^{25}$

\section{THE ROLE OF CROATIAN LOCAL UNITS IN CORONA CRISIS MANAGEMENT}

\subsection{A brief overview of the local government system in Croatia}

The local self-government system in Croatia is organized at two levels, which means that the administrative-territorial division includes municipalities (428) and cities (127) at the first territorial level and counties (20) at the second. The average Croatian municipality with 2,957 inhabitants, and about $86 \mathrm{~km}^{2}$ of the area belongs to

\footnotetext{
22 Art. 17. para. 1 and 3 of the CPA.

23 Art. 34 of the CPA.

24 Art. 18. para. 1, 2, 4, and 6 of the CPA.

25 Counties, [https://www.koronavirus.hr/zupanije/139], Accessed 24 May 2021.
} 
the category of small local units on the European scale. ${ }^{26}$ There are four cities ( $\mathrm{Za}$ greb, Split, Rijeka, and Osijek) with more than 100,000 inhabitants and that serve as regional centres. The 2005 amendment to the legislative framework introduced the category of large cities as units of local self-government, which are centers with more than 35,000 inhabitants. ${ }^{27}$ Counties have an average of about 175,000 inhabitants and an area of about $2,800 \mathrm{~km}^{2}$. Zagreb, as the capital city, represents a special and unique territorial and administrative unit, i.e., it has the status of both a city and a county. Counties, cities and municipalities are self-government units with their own scope of affairs, supplemented with delegated state administration functions (predominantly the capital city of Zagreb, counties, and large cities). Forms of submunicipal decentralization also exist, with the purpose of citizens' participation in decision-making on local affairs of direct and daily impact on their lives and work in more than 3,500 sub-municipal councils. In addition, citizens can also participate in the election of local committee members, in local referenda, start citizens' initiatives and directly participate in discussions convened by the local assembly. However, the forms of direct participation are not widely used by citizens despite their potential to be very useful participation tools and a means for influencing decision-making processes. ${ }^{28}$

Furthermore, the weaknesses of territorial structure and functions which have appeared to be too fragmented reflect on local units' functioning, capacities and local services. ${ }^{29}$ The financial and personal capacities of local governments are weak in general and are unable to provide equal quality and scope of local services to citizens. These circumstances also reflect on local unit responses to the challenges posed by the corona crisis.

26 Ivanović, M., Problemi malih općina u svjetlu nove regulacije lokalne samouprave, in: Koprić, I.; Đulabić, V. (eds.), Dvadeset godina lokalne samouprave u Hrvatskoj, Institut za javnu upravu, Zagreb, 2013, pp. 201-222.

27 A total of seventeen cities.

28 Out of 15 local referenda in the past 20 years, only 3 were successful (Blagojević, A.; Sesvečan, A. Ustavnopravni okvir referendum u RH: trenutno stanje i budući izazovi, Zbornik radova Pravnog fakulteta u Splitu, Vol. 56, No. 4, 2019, pp. 866-867).

29 Domestic experts warned of the problems of local governance during the implementation of radical local government reform in the early 1990s, the irrationality of Croatia's territorial organization, the need for reorganization, and the implementation of functional and fiscal decentralization of the system. See: Ivanišević, S., Glavni problemi i mogući pravci reforme lokalne samouprave u Hrvatskoj, in: Pusić, E. et al., Javna uprava u demokratskom društvu, Institut za javnu upravu and Organizator, Zagreb, 1999, pp. 111-120; Jurlina-Alibegović, D., Financiranje lokalne samouprave, in: Ott, K.; Bajo, A; Pitarević, M. (eds.), Fiskalna decentralizacija u Hrvatskoj, Institut za javne financije, Zagreb, 2002, pp. 92-106; Koprić, I., Teritorijalna organizacija Hrvatske: stanje, kriteriji za prosudbu racionalnosti i prijedlog novog sustava, in: Barbić, J. (ed.), Nova hrvatska lokalna i regionalna samouprava, HAZU, Zagreb, 2010, pp. 109-143. 


\subsection{Croatian local units in the COVID-19 crisis: challenges and results}

There is no region in Croatia that has not been affected by the pandemic. The virus first appeared in the Primorje-Gorski Kotar, Zagreb, and Istria counties, and then it spread to southern, central, and eastern Croatia. Požega-Slavonia and Virovitica-Podravina counties were the last to record the infection. In mid-February 2021, the average rate of infection was 127.3 cases per 100,000 inhabitants, while the highest rate was recorded in Split-Dalmatia (218.9 cases), Medimurje (206.5 cases), Lika-Senj (168.2 cases), and Dubrovnik-Neretva County (165 cases). ${ }^{30}$

In the fight against a pandemic, the regional headquarters exercise two types of authority. The first consists of proposing measures to the Headquarters, which concern a certain area or the entire county. The county headquarters collect information from the local headquarters' area and have the best insight into the pandemic movement. The second authority relates to independent decision-making on measures to be applied in the county. Such decisions most often refer to educational policy, restricting the work of city services, catering facilities and shopping centers, activating isolation units for COVID-19-positive patients, postponement of sports meetings, and permission for recreational fishing and hunting activities. ${ }^{31}$

Local headquarters make decisions and recommendations in co-operation with the executive leaders of local units. Researching the Government's official website, we identified several areas in which decisions on necessary measures were made. ${ }^{32}$ The data were collected for those cities for which information on measures was published. In the case of cities where the data were incomplete or unclear, their official gazette was analyzed. The first group of measures relates to educational policy, i.e., deciding on the application of a certain model of teaching for primary and secondary schools, wearing protective mask in classrooms and indoor schools, and temporary closure of kindergartens. The second measures relate to sports policy, i.e., the postponement of training on football fields, sports halls, small sports fields, and public sports, cultural and other gatherings. Third, measures in the field of service activities include a ban on nightclubs, bars, catering establishments, and adjusted working conditions for shopping centers, shops, bakeries, and retail markets. The fourth and fifth areas relate to utilities and public transport services. The recycling yard services and the removal of bulky waste were suspended, and a

30 NIPH, Coronavirus disease 2019. Report for the previous 7 days and daily report for the Republic of Croatia on the day February 15, 2021, [https://www.koronavirus.hr/UserDocsImages/Dokumenti/Tjedno\%20 izvje\%C5\%A1\%C4\%87e\%20za\%2015.2.pdf?vel=613594], Accessed 1 March 2021.

31 Counties, [https://www.koronavirus.hr/zupanije/139], Accessed 17 January 2021.

32 Official Government website for timely and accurate information on the coronavirus, https://www. koronavirus.hr/, Accessed 12 February 2021. 
special regime of public transport was introduced. During both waves, some bus lines were canceled, while in the first wave, traffic between different counties was additionally canceled. Some cities have established an Emergency Service or have agreed to cooperate with the Red Cross to deliver supplies or pay bills to the elderly (e.g. Slavonski Brod, Umag, Buje, Labin, Rovinj, Krapina, Rijeka, Varaždin, Velika Gorica, Gospić, and Osijek).

After a general overview, the following chapters analyze the areas of local governance that faced the most challenges during the crisis. For each area, the measures taken by large cities and county centers to achieve effective civil protection are presented.

\subsection{Political steering of the crisis management by the local executive leaders}

As in most countries, in Croatia, we see an increase in the concentration of political influence in the executive branch as one of the pandemic consequences. At the central level, it is the Government's influence, and at the lower territorial levels, local executive leaders (commissioners, mayors, and prefects). Executive leaders of local units have been given a number of new tasks, as described in chapter 3.2. Given that they are entrusted with overall responsibility for running local crisis management, they needed to strengthen coordination skills as well as remote management skills. ${ }^{33}$ During the crisis, in twelve of the 25 cities observed, mayors were infected with COVID-19 or were in isolation at home. ${ }^{34}$ Mayors of the cities of Požega and Slavonski Brod were hospitalized and left management to their deputies, while others state that they were able to continue to direct their administrations through working from home, by phone or online. As a rule, mayors have a satisfactory level of communication and co-operation with local and regional headquarters (which is often pointed out in media statements of chiefs of regional headquarters) and continued to successfully direct and supervise the work of local administrations and services during the lockdown. ${ }^{35}$

33 Weisband, S. P., New Challenges for Leading at a Distance, in: Weisband, S. P. (ed.) Leadership at a Distance. Research in Technologically-Supported Work, New York and London, 2007, pp. 1 - 30.

34 These are the mayors of the cities of Bjelovar, Čakovec, Dubrovnik, Koprivnica, Osijek, Pazin, Požega, Pula, Slavonski Brod, Varaždin, Vukovar, and Zadar (the data were collected by web content research).

35 For example: "The city administration functions without interruption regardless of the current situation and...we do our tasks every day and we are available to citizens and services" (mayor of the City of Split, 2020, [https://slobodnadalmacija.hr/split/koronavirus-i-u-banovini-andro-krstulovic-opara-obavijestio-zaposlenike-njih-vise-od-400-da-mogu-ocekivati-pozive-epidemiologa-1012790], Accessed 28 May 2021), or "I would like to note that the effective functioning of the city administration due to the new situation...in our area has not been called into question" (mayor of the City of Popovača, 2020, [https://www.popovaca.hr/vijesti/136-uncategorised/10235-gradonacelnik-josip-miskovic-pozitivan-na-covid-19], Accessed 28 May 2021). 
In addition to the civil protection headquarters, the most frequently mentioned operational partners of the local units were the city red cross societies, police administration, voluntary and public fire brigades, city utilities, Home Help institutions (all of the observed cities), ${ }^{36}$ but also the Community of Technical Culture (City of Dubrovnik), Croatian Chamber of Pharmacists (City of Opatija), the Association of Hairdressers (City of Petrinja) and associations of volunteers such as the Association SKANI 50+ (City of Rijeka). ${ }^{37}$ In accordance with the epidemiological situation in each local unit, the mayors also coordinate the work of narrow teams of local headquarters with the territorially competent public health institutes in the area of enhanced supervision of social service providers in the social welfare system..$^{38}$

The mayors also cooperates with clinical hospital centers in their area, family and dental medicine teams, as well as psychological counseling teams for children and adults. ${ }^{39}$ Information on COVID-19 info centers and anonymous psychological help is regularly published on the official websites of the cities. Unlike the others, the cities of Koprivnica, Krapina, Sisak, Varaždin, and Virovitica have not provided local telephone line for psychological assistance to citizens but refer to telephone lines provided at the county level. The City of Rijeka has also launched a Website for online psychological counseling for young people. ${ }^{40}$ Finally, in cooperation with the crisis teams, the mayors of all of the observed cities have to put a lot of effort into the procurement of protective equipment such as respiratory masks, disposable suits and disinfectants. ${ }^{41}$

36 Public or private institutions have been established in nineteen cities, while in six cities home help services is provided by the Red Cross or the Center for Social Welfare (the data were collected by web content research).

37 For more details, see: Šogorić, S., Hrvatska iskustva rukovodenja COVID-19 krizom na lokalnoj razini, Epoha zdravlja, Vol. 13, No. 22, 2020.

38 Decision on the necessary measure of enhanced control of the implementation of the Guidelines for the Prevention and Suppression of the COVID-19 Epidemic for Social Service Providers in the Social Welfare System, Official Gazette No. 99/20.

39 It is important to involve the community in planning and implementing specific psychosocial support activities (as well as all activities in response to a crisis event), thus protecting the interests and needs of those affected and restoring a sense of control over the situation (Juen, B. et al., Psihosocijalna podrška i psihološka prva pomoć u kriznim situacijama Priručnik za predavače za obuku voditelja timova, Innsbruck, 2018, p. 13).

40 Free online psychological counseling for young people from Rijeka, [https://svejeok.hr/], Accessed 1 April 2021.

41 The data were collected by researching the official websites of the cities and the daily press. 


\subsection{Adjustments of the local administration and service delivery}

Observing the micro-level, organizational adjustments were made in buildings of public bodies and public services in order to minimize the risk of infection of employees and citizens. All offices had to be adapted to the new spacing rules of at least 1.5 - 2 meters, including strict distance and hygiene rules. In terms of functional adaptations, we have identified several areas. First, local administrations needed to adapt to additional online platforms for communication and teleworking. Since they either did not receive clients at all or were working parttime, the observed cities strengthened their activities on official websites and social networks and increased their visibility in the virtual environment. They have set up a COVID-19 info telephone due to the high demand for information. Many citizens' inquiries relate to the interpretation of the isolation and self-isolation measures, the emergency care and the local regulations for the opening of schools and day care centers, travel opportunities to and from Croatia, and issues related to vaccination. Inquiries from the local economy tend to relate to the right to salary compensation during self-isolation, the right to cash benefits for the duration of unemployment and the right to health insurance, the right to installment payment of deferred tax liabilities, etc. ${ }^{42}$

Second, local public services were also closed to work with customers and users. This applies in particular to health, educational and cultural institutions, utilities, and sports halls. Public transport services have also been limited, most transport lines have been suspended, and the remaining number of passengers are allowed to travel in one means of transport.

Third, an area that has been improved in terms of functionality is e-government. Through the e-Citizens system, a number of innovations have been introduced that make it easier and faster for citizens to communicate with the public sector and contribute to the transparency of the provision of public services. For example, services of issuing e-Passes, electronic records from the registers of non-profit persons, the system of payment of e-Fees, submitting applications for exercising the right to a pension, applying for student scholarships, registering children for kindergarten, etc. ${ }^{43}$ Of the observed cities, only the City of Sisak does not offer e-services through the official website.

Fourth, during the pandemic, there was a need for intensified supervision of certain social activities in accordance with a series of decisions and instructions issued

\footnotetext{
42 The most frequent inquiries of citizens were then published on the official websites of the Tax Administration, the NIPH, the Headquarters, the Ombudsman, ministries and the Croatian Tourist Board.

43 Personal user box, [https://pretinac.gov.hr/KorisnickiPretinac/eGradani.html], Accessed 1 April 2021.
} 
by the Headquarters and the NIPH. For example, movement between local units was possible only with the issuance of passes. Therefore, checkpoints were set up at the crossings between the units where police officers controlled the possession of passes in relation to all forms of transport. ${ }^{44}$ Free movement of citizens is also limited by isolation and self-isolation measures which were primarily subject to active and passive health surveillance. But in case of violation of the measures of mandatory wearing of protective masks or isolation, the police intervened by collecting fines. Inspectors and members of civil protection and municipal wardens have basic powers in overseeing the implementation of measures banning public and private gatherings (eg. requesting access to the public document of a person suspected of having committed a misdemeanor, issuing misdemeanor warrants and fines). ${ }^{45}$ However, in the event of the need to apply coercive or detention measures, inspectors may justifiably request the intervention of the police. In addition, the city headquarters of the City of Rijeka, Osijek, and Đakovo also established drone surveillance by the Public Fire Brigade. ${ }^{46}$ Coordinated tourist and sanitary inspectors in the summer period controlled the legality of the work of catering facilities and compliance with epidemiological measures. ${ }^{47}$

Finally, at the time of the pandemic, the rate of domestic violence rose sharply globally. ${ }^{48}$ Therefore, the City of Zagreb directs additional part of its human and financial resources to the promotion of gender equality and the prevention of gender-based violence. It supports three shelters for victims of domestic violence as well as six counseling centers organized by the City's social welfare institution and civil society organizations. ${ }^{49}$ On their official websites, another eleven cities publish general information on local services in the field of protection of victims

44 Instructions to the police directorate - pass control, 2020, [https://civilna-zastita.gov.hr/UserDocsImages/CIVILNA\%20ZA\%C5\%A0TITA/PDF_ZA\%20WEB/Uputa-za\%20kontrolu\%20e-Propusnica.pdf], Accessed 8 April 2021.

45 Law on Communal Activities, Official Gazette No. 68/18, 110/18, 32/20.

46 Counties, [https://www.koronavirus.hr/], Accessed 16 March 2021

47 Tourist and sanitary inspectors from 1 July in coordinated inspections - Elements of control in supervision, 2020, [https://dirh.gov.hr/vijesti/turisticki-i-sanitarni-inspektori-od-1-srpnja-u-koordiniranim-inspekcijskim-nadzorima-elementi-kontrole-u-nadzoru/309], Accessed 17 March 2021.

48 European and world statistics in the situation of pandemic and corona crisis record an increase in violence against women by more than $30 \%$ (Commission for Gender Equality of the County of Istria, 2020, [https://translate.google.hr/?hl=en\&tab=rT\&sl=hr\&tl=en\&text=Povjerenstvo\%20za\%20 ravnopravnost $\% 20$ spolova $\% 20$ Istarske $\% 20 \%$ C5\%BEupanije\&op=translate], Accessed 17 March 2021).

49 City of Zagreb team for prevention and fight against violence against women and domestic violence and Commission for Protection from Domestic Violence, Joint press release and information on services for victims in the City of Zagreb, Zagreb, 2 April 2020. 
of violence (Bjelovar, Koprivnica, Krapina, Pazin, Požega, Pula, Rijeka, Samobor, Varaždin, Vukovar, and Zadar).

\subsection{Local government financial burdens}

Local units ended the pandemic year with a drop in revenue of slightly less than $4 \%$, or a loss compared to 2019 of approximately 775 million HRK. The budget revenues of all 555 local units last year were 27.86 billion HRK, with cities doing significantly worse than municipalities, which had only a slight minus $0.2 \%$, and counties, which recorded revenue growth of more than $7 \% .{ }^{50}$ More than 2.3 billion HRK from the EU was invested in local budgets last year, a third more than a year earlier, which significantly mitigated the loss of other revenues from domestic sources (income tax, utility fees, utility contributions and real estate transfer tax). ${ }^{51}$ In addition to tangible and intangible costs for the work of local headquarters, part of the city funds was spent on the purchase of protective masks and disinfectants, information and communication equipment, financing of kindergarten services, school meals, and extended stays, and measures to help the economy (the award of grants, a temporary exemption from paying utility bills and rents for restaurants, the introduction of free parking around health facilities, and the payment of funds to the Red Cross). ${ }^{52}$

However, in 2020 cities have managed to maintain budget and investment liquidity thanks to an interest-free loan from the Ministry of Finance. ${ }^{53}$ The loan funds are used exclusively to finance the public expenditures and expenses necessary to

50 Municipalities are the most successful beneficiaries of EU funds, and 700 million kuna (+64\%) went into their budgets from the EU last year, while incomparably stronger cities withdrew 1.1 billion HRK for their programs (Budget loss of hundreds of millions of kunas: How cities, counties and municipalities fared in the pandemic year, 2021, [https://www.vecernji.hr/vijesti/lokalne-jedinice-diljem-hrvatske-zavrsile-u-minusu-od-775-milijuna-kuna-je-li-za-sve-kriva-korona-1479893], Accessed 29 March 2021).

51 There was a decline in local tax revenues of 903 million HRK (-6\%), utility contributions were collected $14 \%$ less ( -132 million HRK), $11 \%$ less utility fees and $20 \%$ less rental income ( -162 million HRK). The least income was collected for the sojourn tax, only 4 million HRK compared to 100 million a year earlier. There were also fewer purchase and sale transactions, as 948 million were collected from real estate sales tax compared to 1.14 billion in 2019. The tax on holiday homes was well collected, slightly more than before, while the consumption tax was almost halved. More money went into county budgets than from road vehicle taxes (ibid.).

52 City measures in the fight against the coronavirus, [https://gradonacelnik.hr/u-fokusu/pandemija-korone-zatvaraju-se-skole-i-vrtici-u-istri-gradovi-otkazuju-sva-javna-dogadanja-zatvaraju-se-gradski-bazeni-i-dvorane/], Accessed 29 March 2021.

53 Instructions on the manner of disbursement of interest-free loan to local and regional self-government units, the Croatian Pension Insurance Institute and the Croatian Health Insurance Institute, Official Gazette No. 46/20. 
perform the basic tasks and functions of the borrower. The negative trend of revenue collection continued in the first quarter of 2021, and it is expected that by the end of the year, city revenues will decrease by an additional 900 million HRK. A special problem for the liquidity of cities in the second half of the year is the increased income tax refund for people under 30, which, together with the effects of the pandemic and tax reform, will leave cities without a main source of income for several months at the beginning of the new term. The Ministry of Finance is expected to provide a new interest-free loan to the most exposed cities so that the tax refund to citizens can be carried out without difficulty before the season, and the cities retain liquidity. ${ }^{54}$

A step further that local units have taken in relation to central institutions is the decision to reduce the city administration's salaries and companies and institutions owned by the city. During the "first wave," the mayors of the 17 observed cities $^{55}$ decided to reduce the salaries of the city administration and companies and institutions owned by the city by $2 \%$ to $50 \%$ for a period of one to six months. Seven of them (Koprivnica, Samobor, Split, Velika Gorica, Vinkovci, Virovitica, and Varaždin) applied a proportional reduction: the salaries of the lowest-paid employees were not reduced, and the salaries above the minimum amount were reduced by a higher percentage according to the amount. The cities of Bjelovar, Čakovec, Vinkovci, Virovitica, and Zagreb abolished the payment of Easter and Christmas bonuses, regresses, and jubilee awards. Compensation to local council presidents and councilors and payments to political parties were abolished in the cities of Dubrovnik, Čakovec, Koprivnica, Split, and Virovitica. ${ }^{56}$ In this way, it was also possible to cover a part of the budget losses.

\subsection{Challenges to local democracy}

One of the important aspects of civic participation are local elections. ${ }^{57}$ Regular local elections were held in Croatia on May 16, and May 31, 2021. Before the

54 Budget loss of hundreds of millions of kunas: How cities, counties and municipalities fared in the pandemic year, 2021, [https://www.vecernji.hr/vijesti/lokalne-jedinice-diljem-hrvatske-zavrsile-u-minusu-od-775-milijuna-kuna-je-li-za-sve-kriva-korona-1479893], Accessed 29 March 2021.

55 The City of Rijeka has not implemented this measure. No online information was available for the cities of Gospić, Kaštela, Krapina, Osijek, Požega, Slavonski Brod, and Vukovar, nor did they respond to the author's inquiry about the measure in question.

56 Information was collected on Counties, [https://www.koronavirus.hr/zupanije/139], Mayor, [https:// gradonacelnik.hr/], official websites of the cities, and by the author's individual inquiries to the cities.

57 For the catalogue of standards of local democracy in Croatia, see: Dobrić Jambrović, D., European Standards in Regulating Public Participation on Subnational Levels: The Case of Croatia, in: Nunes Silva, C. (ed.) Contemporary Trends in Local Governance. Reform, Cooperation and Citizen Participation, Springer, Switzerland, 2020, pp. $217-239$. 
elections, a total of $82 \%$ of cities believed that citizens should be additionally encouraged and motivated to participate regardless of the party's election campaign..$^{58}$ Therefore, cities faced the challenge of resolving the conflict between encouraging the highest possible turnout in elections on the one hand, and avoiding mass gatherings in line with epidemiological measures on the other. ${ }^{59}$ In the observed cities, the voter turnout in the first round ranged from $28.23 \%$ to $49.31 \%$, and in the second round from $14,23 \%$ to $51,05 \%$. A comparison with voter turnout in the 2017 elections is only available concerning counties. In 2021, there was an increase in voters in the first round in eleven counties (from $0.35 \%$ to $3.8 \%$ ), and in the second round in ten counties (from $0.8 \%$ to $10.7 \%$ ). ${ }^{60}$

In addition to local political parties, local councils/county assemblies also faced a challenge. The Ministry of Administration has instructed all local and regional units that the representative bodies must adapt the way they work to the current situation. Therefore, if it is not about the decisions that need to be made and which do not suffer delays due to urgency, a convened session of the representative body may be postponed or canceled. ${ }^{61}$ Also, meetings with citizens in local boards (sub-municipal government) were temporarily restricted. Holding sessions by video conference, communication via e-mail, or using other technologies to hold meetings at a distance, is considered acceptable, especially with regard to the possibility of recording participants and their voting. If there are no other technological solutions, sessions can exceptionally be held by telephone to make a decision that does not suffer a delay. In the latter case, it is necessary to take into account the way of subsequent verification of decision-making. ${ }^{62}$

Sessions of representative bodies are public and the presence of the public can be excluded only exceptionally, in cases provided by special laws and the general act

58 Association of Cities, Democracy and participation: the role of local governments in encouraging civic participation, 2020, [https://www.udruga-gradova.hr/demokracija-i-participacija-uloga-lokalnih-samouprava-u-poticanju-gradanske-participacije/], Accessed 16 February 2021.

59 An additional challenge is the implementation of elections in accordance with the amendments to the Law on Local Elections, the Law on Local and Regional Self-Government and the Law on the City of Zagreb, which entered into force in December 2020.

60 State Election Commission, [https://www.izbori.hr/site/], Accessed 2 June 2021; official websites of the cities of Kaštela, Samobor, and Vinkovci.

${ }^{61}$ Representative bodies independently assess the urgency of convening sessions. If they deem it necessary to convene an electronic session, it is obliged to hold it in a manner that follows the usual procedure, unreserved participation of each councilor and a statement on each item on the agenda, of which there must be evidence.

62 Ministry of Administration, Sessions of the Representative Body of Local and Regional Self-GovernmentInstructions for Action, Zagreb, 2020, p. 2. 
of the local unit. ${ }^{63}$ In the conditions of holding a session by e-mail or electronic video tool, the presence of the public at the session can be ensured in a very limited way, regardless of what is prescribed by law or general act. The first restriction is the ban on gathering more than a certain number of people in one place, which means that the public cannot be invited to follow the session from the immediate vicinity of the chairman. Attendance in case of a session via video service is possible but requires prior preparation (timely notification of the public about the manner of attending the session, with the announcement of the agenda, appropriate technical instructions, timely registration of those who want to participate, etc.). ${ }^{64}$ Fifteen observed cities publish recordings of the sessions on their official websites, YouTube channel or Facebook page. Other nine cities held the session via video conference with the possibility for citizens to receive an audio recording upon request to the information officer. Only the City of Požega held live sessions throughout the pandemic. ${ }^{65}$

\section{CONCLUSION}

The crisis caused by the COVID-19 pandemic imposes demands on all levels of government, especially local and regional ones, to provide emergency services, curb the spread of the disease, mitigate the social and economic consequences of the pandemic, and coordinate recovery efforts. Taking into account the results of the research, we conclude that changes in the approach to local governance are necessary for local units to better adapt during the crisis, but also to effectively solve the problems of the post-crisis period. We identified several reasons why reform of the governance system is necessary to accelerate the response of units to socio-economic, political and other crises. First, crisis management in any context leads to strengthening centralization processes in the country. ${ }^{66}$ Amendments to the CPA entrusted the Headquarters with very broad powers. When special circumstances occur that endanger citizens' lives and health, the Headquarters makes the necessary decisions and instructions that regional and local headquarters must implement. On the one hand, it is an insufficiently defined and extremely broad formulation of the phrase "instructions and decisions" and, on the other hand, it

63 Art. 37 para. 1 of the Law on local and regional self-government, Official Gazette No. 33/01, 60/01, 129/05, 109/07, 125/08, 36/09, 36/09, 150/11, 144/12, 19/13, 137/15, 123/17, 98/19, 144/20.

64 Ivanović, M., Holding a session of the representative body with the help of technological tools, 2020, [https://informator.hr/vijesti/odrzavanje-sjednice-predstavnickog-tijela-uz-pomoc-tehnoloskih-alata], Accessed 19 February 2021.

65 The City of Požega, [https://www.pozega.hr/index.php?option=com_content\&view=category\&layout=blog\&id=31\&Itemid=292\&limitstart=4], Accessed 20 April 2021.

${ }_{66}$ Boin, A., The Transboundary Crisis: Why we are unprepared and the road ahead, Journal of Contingencies and Crisis Management, Vol. 27, No. 1, 2019, pp. 94-99. 
is about the actual coordination of the work of headquarters at lower territorial levels, which is assumed not to have been implemented before. The Headquarters, the Minister of Health and the Director of the NIPH have issued numerous decisions, instructions and guidelines that form the basis for adapting a greater range of organizational and functional elements of governance and public service delivery. Both local and regional governments adapted to the selected national crisis management strategies. Therefore, we also see an increase in the concentration of political influence in the executive branch as one of the pandemic consequences. At the central level, it is the Government's influence, and at the lower territorial levels, local executive leaders. The CPA and the APPID have activated many new powers for the local executive leaders compared to those that they exercise out of crisis situations. Therefore, we accept the first hypothesis as well-founded because we assumed that the consequence of the crisis would be a greater concentration of power in the executive body of local units.

Second, in almost all areas of public service delivery, there have been adjustments in the work of public services. The greatest pressure was put on health institutions. Family physicians have adapted their actions by inviting citizens to try to resolve their inquiries by phone and e-mail whenever possible. In hospitals, part of the departments has been converted to COVID departments, reducing the capacity to receive patients. Preference is given to emergencies, as well as in terms of performing surgical procedures. A large decline in the quality of services provided is also observed at all levels of education. School institutions were closed on several occasions and online classes were organized. Although all relevant IT platforms are applied, teaching units are processed in a concise form and students' independent work is overemphasized. The objectivity of taking the exam has also been violated. Despite the use of certain safety systems, there are frequent examples of unethical student behavior when taking exams. Furthermore, the provision of a range of sports, cultural and transport services has been blocked. Except for the observed cities, an additional problem for small local units is the inadequate administrative-territorial division of the state. The citizens of municipalities and towns experienced the consequences of the existing territorial organization more than ever before when during the "first wave" the Headquarters decided to ban the movement of citizens between different local units. Since most citizens live in small local units, some of which do not have public services, they have been denied basic services.

Third, in the last year, information as the lowest level of civic participation is mostly practiced. Citizens are informed through official websites or newspapers, leaflets, brochures. Regarding the consultation process, local authorities use online platforms, which limits the participation of citizens who do not have IT equip- 
ment or do not use internet services. Also, there is no possibility of civic participation through direct onsite dialogue. ${ }^{67}$ City councils and local committees were holding sessions online or by telephone, which greatly limits citizens' participation in local governance. Considering that the second hypothesis contains an assumption that the crisis will reduce the quality of local public services and impose restrictions on local democracy, we conclude that it is also valid.

Finally, due to shortcomings in the regulation and implementation of crisis management in Croatia, we provide recommendations for improving resistance to similar challenges in the future. The recommendations were formulated taking into account the existing regulatory framework and experience of the surveyed cities in overcoming challenges. ${ }^{68}$ First, strengthening multilevel governance and local autonomy. As crisis management requires rapid decision making and centralization, it has led to a further weakening of multilevel governance mechanisms in the name of efficiency and security. However, respecting the principle of subsidiarity and democratic local self-government, it is extremely important to recognize the key role of local authorities in crisis management and to involve them in the decision-making process during and after the crisis period. Through continuous cooperation, the representatives of national and local authorities should find an effective way to strengthen the role of local units as equal decision-makers and executors of agreed agendas to avoid weakening their autonomy and the principle of subsidiarity ${ }^{69}$ Also, there are different models of multilevel governance at the local and regional level. We recommend their application to strengthen the cooperation of cities and counties in shaping effective public policies and strategies. ${ }^{70}$

Second, strengthening functional and fiscal decentralization to increase the capacity of cities as executors of agendas. Decentralization of public functions contributes to increasing efficiency in the provision of public services since local governments, as the level closest to the citizens have the best insight into the needs of the local population. It also enables the mobilization of public revenues while reducing the costs of providing public services, harmonization of responsibilities

67 For more details on public consultation and dialogue, see Dobrić, D., Implementing open government policies on subnational levels, SGEM Conference on Political Sciences, Law, Finance, Economics \& Tourism, No. 1, 2015, pp. 175 - 182.

${ }_{68}$ We note that research on the experience of municipalities and towns would certainly show a greater number of problems and the following recommendations would not be sufficient to improve their role in times of crisis.

69 Central to the multilevel governance concept, is the recognition that delivering policies, actions and strategies, is more effective when working together, across different levels of government. (Group of authors, A Guide to Multi-Level Governance. For Local and Regional Public Authorities, Coopenergy Consortium, 2015, p. 2.)

70 For example, six different models of collaboration are elaborated in the Guide. (ibid., p. 19-20.) 
for local public expenditures with available financial resources, strengthening of local revenues and cooperation between different levels of government. ${ }^{71}$ In addition to decentralization of public affairs, ${ }^{72}$ large cities should be provided with higher public revenues compared to the category of towns and municipalities. ${ }^{73}$ In this way, they could fund not only city services but also services of wider areas that gravitate to them.

Third, ensuring equal access to public services. During the lockdown, residents of the observed cities had access to public services regardless of how their work was adjusted. However, this does not apply to residents of surrounding towns and municipalities who use the city services in non-crisis times (since some services are not organized in their area). Therefore, a necessary precondition for rational performance of public services is a certain size of the local unit. As the number of inhabitants increases and the area expands, the financial capacity of the local unit also increases. ${ }^{74}$ The author supports an existing proposal to reduce the number of local units by creating an urban polycentric network consisting of 100 to 120 units (depending on the geographical specifics of each area) with similar scope and powers. ${ }^{75}$

Fourth, increase the level of civic participation. In addition to service delivery that plays a key role in ensuring citizen well-being and combating distrust, new ways of civic participation need to be implemented. Emphasis should be placed on higher levels of participation, i.e. dialogue and partnership. First of all, local authorities should make an effort to motivate citizens for active participation. For example, they could develop and deliver high-quality civic education that teaches people to respect and value democratic freedoms. After that, resources should be invested in additional participation mechanisms such as regular Q\&A meetings on the

71 Jurlina-Alibegović, op.cit. note 29, p. 94.

72 Decentralized functions of primary and secondary education, health, social welfare and firefighting are performed by about forty cities (out of a total of 127). The reason for this is the insufficient financial, organizational and administrative capacity of most local units. Instead, decentralized tasks are performed by counties. (Koprić, I., Suvremeni trendovi u razvoju lokalne samouprave i hrvatska lokalna i regionalna samouprava, in: Koprić, I. (ed.), Europeizacija hrvatske lokalne samouprave, Institut za javnu upravu, Zagreb, 2018, p. 36).

73 Gunnarsson stressed the importance of financial autonomy and resilience of local governments to deal with this crisis, but also their better adjustment for the future. This is crucial because local units often depend on other levels of government to provide basic resources for service delivery. (Group of authors, Local Democracy, UCGL-metropolis-UNHABITAT, 2020, p. 7).

74 There are exceptions to this rule. The increase in territorial units that are less populated and have a less developed economy due to various circumstances usually has the opposite effect. (Koprić, I., Teritorijalna..., op.cit., note 29) There may be problems with maintaining a wider road network, more expensive infrastructure, physical planning, housing, etc.

75 Koprić, I., Suvremeni..., op. cit., note 72, p. 42. 
official website or social networks with the participation of local official, servants and citizens; online meetings of citizens with public service heads to improve local services; publication of infographics, data visualization, and videos to stimulate community debate; participatory budgeting or surveys on the topic of interest to residents. Meetings can be organized thematically, with a particular councilor or head of an administrative department. Representatives of public services and citizens could form a working group whose task will be to co-draft strategies for improving service delivery and joint decision-making. Also, citizens' representatives should be involved in the process of monitoring the fulfillment of agreed strategic goals, etc.

Finally, cities need to practice inclusion-oriented innovations. Although digital technology is used as a means of strengthening democracy, it also leads to a technological gap and affects social exclusion. Especially in relation to the elderly, low-income families and people with disabilities. True democratic inclusion is not only achieved through the participation of as many citizens as possible but also about the involvement of target groups. Therefore, we suggest combining online platforms with participation through telephone calls and surveys, audio conferences, delivery of press products and household surveys, thematic outdoor events while maintaining social distance, etc.

The biggest challenges imposed by the crisis are ensuring deliberative and inclusive governance, maintaining the accountability of institutions, avoiding restrictions on fundamental rights and ensuring the quality of public services. The proposed mechanisms should contribute to greater transparency, accountability, responsiveness and efficiency of local government in times of crisis, and beyond.

\section{REFERENCES}

\section{BOOKS AND ARTICLES}

1. Ansell, C.; Boin, A.; Keller, A., Managing Transboundary Crises: Identifying Building Blocks of an Effective Response System, Journal of Contingencies and Crisis Management, Vol. 18, No. 4, 2010, pp. 195-207

2. Blagojević, A.; Sesvečan, A., Ustavnopravni okvir referendum u RH: trenutno stanje i budući izazovi, Zbornik radova Pravnog fakulteta u Splitu, Vol. 56, No. 4, 2019, pp. 835-876

3. Boin, A., The Transboundary Crisis: Why we are unprepared and the road ahead, Journal of Contingencies and Crisis Management, Vol. 27, No. 1, 2019, pp. 94-99

4. City of Zagreb team for prevention and fight against violence against women and domestic violence and Commission for Protection from Domestic Violence, Joint press release and information on services for victims in the City of Zagreb, Zagreb, 2 April 2020 
5. Dobrić, D., Implementing open government policies on subnational levels, SGEM Conference on Political Sciences, Law, Finance, Economics \& Turism, No. 1, 2015, pp. 175-182

6. Dobrić Jambrović, D., European Standards in Regulating Public Participation on Subnational Levels: The Case of Croatia, in: Nunes Silva, C. (ed.) Contemporary Trends in Local Governance. Reform, Cooperation and Citizen Participation, Switzerland, 2020, pp. 217-239

7. Government, Report on the effects of the implementation of measures under the Act on the Protection of the Population from Infectious Diseases during the COVID-19 pandemic caused by the SARS-COV-2 virus in the Republic of Croatia for the period from 11 March 2020 to 15 January 2021, Zagreb, 2021

8. Group of authors, A Guide to Multi-Level Governance. For Local and Regional Public Authorities, Coopenergy Consortium, 2015

9. Group of authors, Local Democracy, UCGL-metropolis-UNHABITAT, 2020

10. Ivanišević, S., Glavni problemi i mogući pravci reforme lokalne samouprave u Hrvatskoj, in: Pusić, E. et al., Javna uprava u demokratskom društvu, Institut za javnu upravu and Organizator, Zagreb, 1999, pp. 111-120

11. Ivanović, M., Problemi malih općina u svjetlu nove regulacije lokalne samouprave, in: Koprić, I.; Đulabić, V. (eds.), Dvadeset godina lokalne samouprave u Hrvatskoj, Institut za javnu upravu, Zagreb, 2013, pp. 201-222

12. Juen, B. et al., Psihosocijalna podrška i psihološka prva pomoć u kriznim situacijama Priručnik za predavače za obuku voditelja timova, Innsbruck, 2018

13. Jurlina-Alibegović, D., Financiranje lokalne samouprave, in: Ott, K.; Bajo, A; Pitarević, M. (eds.), Fiskalna decentralizacija u Hrvatskoj, Institut za javne financije, Zagreb, 2002, pp. 92-106

14. Koprić, I., Glavna obilježja postojećeg i prijedlog novog teritorijalnog ustrojstva Hrvatske - zašto nam treba teritorijalna reorganizacija, in: Koprić, I. (ed.) Reforma lokalne i regionalne samouprave u Republici Hrvatskoj, Institut za javnu upravu - Pravni fakultet Zagreb, Zagreb, 2013, pp. 1-30

15. Koprić, I., Suvremeni trendovi u razvoju lokalne samouprave $i$ hrvatska lokalna i regionalna samouprava, in: Koprić, I. (ed.), Europeizacija hrvatske lokalne samouprave, Institut za javnu upravu, Zagreb, 2018, pp. 272-342

16. Koprić, I., Teritorijalna organizacija Hrvatske: stanje, kriteriji za prosudbu racionalnosti i prijedlog novog sustava, in: Barbić, J. (ed.), Nova hrvatska lokalna i regionalna samouprava, HAZU, Zagreb, 2010, str. 109-143

17. Koprić, I.; Škarica, M., Evaluacija neposrednog izbora načelnika u Hrvatskoj nakon dva mandata: korak naprijed, dva nazad, in: Gongeta, S.; Smoljić, M. (eds.) Zbornik radova 7. međunarodne konferencije "Razvoj javne uprave", Veleučilište 'Lavoslav Ružička' u Vukovaru, Vukovar, 2017, pp. 156-172

18. Ministry of Administration, Sessions of the Representative Body of Local and Regional SelfGovernment - Instructions for Action, Zagreb, 2020

19. Šogorić, S., Hrvatska iskustva rukovodenja COVID-19 krizom na lokalnoj razini, Epoha zdravlja, Vol. 13, No. 22, 2020 
20. Weisband, S. P., New Challenges for Leading at a Distance, in: Weisband, S. P. (ed.) Leadrship at a Distance. Research in Technologically-Supported Work, New York and London, 2007, pp. 1-30

\section{EU LAW}

1. Council Decision (EU) 2018/1993 on the EU Integrated Political Crisis Response Arrangements [2018] OJ L320/28

2. Council, The EU Integrated Political Crisis Response - IPCR - Arrangements Government of the Republic of Croatia, Bill on amendments to the Act on the protection of the population from infectious diseases with the Final Bill (PZ n. 921), 9 April 2020

\section{LIST OF NATIONAL REGULATIONS AND ACTS}

1. Act on the Protection of the Population from Infectious Diseases, Official Gazette No. $79 / 07,113 / 08,43 / 09,130 / 17,114 / 18,47 / 20,134 / 20$

2. Civil Protection Act, Official Gazette No. $85 / 15$, 118/18, 31/20

3. Decision on the amendment to the Decision on temporary prohibition and restriction of border crossings of the Republic of Croatia, Official Gazette No. 139/20

4. Decision on the composition of the headquarters, the manner of work and the conditions for the appointment of the Chief, Deputy Chief and members of the Civil Protection Headquarters, Official Gazette No. 126/19, 17/20

5. Decision on the necessary measure of enhanced control of the implementation of the Guidelines for the Prevention and Suppression of the COVID-19 Epidemic for Social Service Providers in the Social Welfare System, Official Gazette No. 99/20

6. Decision on the prohibition of leaving the county based on the place of permanent residence or temporary stay in the Republic of Croatia, Official Gazette No. 141/20

7. Decision on the structure, preparation and operation of the Croatian Red Cross in crisis situations, 14 December 2016

8. Instructions on the manner of disbursement of interest-free loan to local and regional selfgovernment units, the Croatian Pension Insurance Institute and the Croatian Health Insurance Institute, Official Gazette No. 46/20

9. Law on Communal Activities, Official Gazette No. 68/18, 110/18, 32/20

10. Law on local and regional self-government, Official Gazette No. 33/01, 60/01, 129/05, 109 /07, 125/08, 36/09, 36/09, 150/11, 144/12, 19/13, 137/15, 123/17, 98/19, 144/20

\section{WEBSITE REFERENCES}

1. Association of Cities, Democracy and participation: the role of local governments in encouraging civic participation, 2020, [https:/www.udruga-gradova.hr/demokracija-i-participacija-uloga-lokalnih-samouprava-u-poticanju-gradanske-participacije/], Accessed 16 February 2021

2. Budget loss of hundreds of millions of kunas: How cities, counties and municipalities fared in the pandemic year, 2021, [https:/www.vecernji.hr/vijesti/lokalne-jedinice-diljem- 
hrvatske-zavrsile-u-minusu-od-775-milijuna-kuna-je-li-za-sve-kriva-korona-1479893], Accessed 29 March 2021

3. City measures in the fight against the coronavirus, [https://gradonacelnik.hr/u-fokusu/ pandemija-korone-zatvaraju-se-skole-i-vrtici-u-istri-gradovi-otkazuju-sva-javna-dogadanjazatvaraju-se-gradski-bazeni-i-dvorane/], Accessed 29 March 2021

4. Commission for Gender Equality of the County of Istria, 2020, [https://translate.google. $\mathrm{hr} /$ ?hl=en \& tab=rT\&sl=hr\&tl=en\&text=Povjerenstvo\%20za\%20ravnopravnost\%20spolova\%20Istarske\%20\%C5\%BEupanije\&op=translate], Accessed 17 March 2021

5. Counties, [https://www.koronavirus.hr/zupanije/139], Accessed 17 January 2021

6. Decision on declaring the COVID-19 epidemic caused by the SARS-CoV-2 virus, 2020, [https://zdravstvo.gov.hr/UserDocsImages/2020\%20CORONAVIRUS/ODLUKA\%20 O\%20PROGLA\%C5\%A0ENJU\%20EPIDEMIJE\%20BOLESTI\%20COVID-19.pdf], Accessed 10 February 2021

7. Deep Knowledge Group, [https://www.dkv.global/covid-safety-assessment-200-regions], Accessed 13 January 2021

8. European Committee of the Regions (2020), The coronavirus crisis and the role of EU regions and cities, [https://cor.europa.eu/en/our-work/EURegionalBarometerDocs/CoR_ Presentation\%20v_final.pdf], Accessed 13 January 2021

9. Free online psychological counseling for young people from Rijeka, [https://svejeok.hr/], Accessed 1 April 2021

10. Government measures, [https://www.koronavirus.hr/vladine-mjere/101], Accessed 13 January 2021

11. Instructions to the police directorate - pass control, 2020, [https://civilna-zastita.gov.hr/ UserDocsImages/CIVILNA\%20ZA\%C5\%A0TITA/PDF_ZA\%20WEB/Uputa-za\%20 kontrolu\%20e-Propusnica.pdf], Accessed 8 April 2021

12. Ivanović, M., Holding a session of the representative body with the help of technological tools, 2020, [https://informator.hr/vijesti/odrzavanje-sjednice-predstavnickog-tijela-uz-pomoctehnoloskih-alata], Accessed 19 February 2021

13. Mayor, [https://gradonacelnik.hr/], Accessed 27 May 2021

14. NIPH, Coronavirus disease 2019. Report for the previous 7 days and daily report for the Republic of Croatia on the day February 15, 2021, [https:/www.koronavirus.hr/UserDocsImages/ Dokumenti/Tjedno\%20izvje\%C5\%A1\%C4\%87e\%20za\%2015.2.pdf?vel=613594], Accessed 1 March 2021

15. Official Government website for timely and accurate information on the coronavirus, [https://www.koronavirus.hr/], Accessed 12 February 2021

16. Personal user box, [https://pretinac.gov.hr/KorisnickiPretinac/eGradani.html], Accessed 1 April 2021

17. Tourist and sanitary inspectors from 1 July in coordinated inspections - Elements of control in supervision, 2020, [https://dirh.gov.hr/vijesti/turisticki-i-sanitarni-inspektori-od1-srpnja-u-koordiniranim-inspekcijskim-nadzorima-elementi-kontrole-u-nadzoru/309], Accessed 17 March 2021 